\title{
Control of tomato bacterial wilt through the incorporation of aerial part of pigeon pea and crotalaria to soil*
}

\author{
Suane C. Cardoso ${ }^{1}$, Ana Cristina F. Soares ${ }^{2}$, Alexsandro dos S. Brito ${ }^{3}$, Francisco F. Laranjeira ${ }^{4}$, Carlos Alberto S. \\ Ledo $^{4}$, Andiale P. dos Santos ${ }^{5}$
}

${ }^{1}$ Graduate student in Agronomy, CAPES assistantship, ${ }^{3} \mathrm{PET}$ assistantship, ${ }^{5} \mathrm{PIBIC}-\mathrm{FAPESB}$ assistantship, ${ }^{2}$ Professor, Lab. Phytopathology and Soil Microbiology, School of Agronomy, UFBA, 44380-000, Cruz das Almas, Bahia, <acsoares@ufba.br>.

${ }^{4}$ Researcher, Embrapa-Mandioca e Fruticultura Tropical, 44380-000, Cruz das Almas, Bahia.

*Part of the Master thesis of the first author, at the Federal University of Bahia (UFBA).

Data de chegada: 25/08/04. Aceito para publicação em: 30/08/05.

1110

\begin{abstract}
Cardoso, S.C.; Soares, A.C.F.; Brito, A. dos S.; Laranjeira, F.F.; Ledo, C.A.S.; Santos, A.P. Control of tomato bacterial wilt through the incorporation of aerial part of pigeon pea and crotalaria to soil. Summa Phytopathologica, v.32, p. 27-33, 2006.

The use of organic matter that improves the physical, chemical and biological soil properties has been studied as an inducer of suppressiveness to soilborne plant pathogens. The objective of this work was to evaluate the effect of different sources and concentrations of organic matter on tomato bacterial wilt control. Two commercially available organic composts and freshly cut aerial parts of pigeon pea (Cajanus cajan) and crotalaria (Crotalaria juncea) were incorporated, in concentrations of 10,20 and $30 \%(\mathrm{v} / \mathrm{v})$, into soil infested with Ralstonia solanacearum. The soil with the fresh organic matter of pigeon pea and crotalaria was incubated for 30 and 60 days before

planting. Tomato seedlings of cv. Santa Clara were transplanted into polyethylene bags with $3 \mathrm{~kg}$ of the planting substrate (infested soil + organic matter). The wilting symptoms and percentage of flowering plants were evaluated for 45 days. All evaluated concentrations with incorporation and incubation for 30 days of aerial parts of pigeon pea and crotalaria controlled $100 \%$ tomato bacterial wilt. With 60 days of incubation, only the $10 \%$ concentration of pigeon pea and crotalaria did not control the disease. These results suggest that soil incorporation of fresh aerial parts of pigeon pea and crotalaria is an effective method for bacterial wilt control.
\end{abstract}

Additional keywords: Lycopersicon esculentum, Ralstonia solanacearum, Cajanus cajan, Crotalaria juncea, organic composts.

\section{RESUMO}

Cardoso, S.C.; Soares, A.C.F.; Brito, A. dos S.; Laranjeira, F.F.; Ledo, C.A.S.; Santos, A.P. Controle da murcha bacteriana do tomateiro pela incorporação da parte aérea de guandu e crotalária no solo. Summa Phytopathologica, v.32, p. 27-33, 2006.

A utilização de materiais orgânicos que melhoram as características físicas, químicas e biológicas do solo vem sendo estudada como indutora de supressividade a fitopatógenos habitantes do solo. Este trabalho teve como objetivo avaliar o efeito de diferentes fontes e concentrações de matéria orgânica no controle da murcha bacteriana do tomateiro. Foram avaliados dois compostos orgânicos comerciais e a matéria fresca cortada da parte aérea de guandu (Cajanus cajan) e de crotalária (Crotalaria juncea), nas concentrações 10, 20 e $30 \%$ (v/v), incorporados no solo infestado com Ralstonia solanacearum. O solo que recebeu a parte aérea de guandu e crotalária foi incubado por 30 e 60 dias, antes do plantio.
Mudas de tomateiro 'Santa Clara' foram transplantadas para sacos de polietileno contendo $3 \mathrm{~kg}$ de substrato (solo infestado + matéria orgânica) e avaliou-se, por um período de 45 dias, o sintoma de murcha bacteriana e a percentagem de plantas com floração. A incorporação e incubação por 30 dias com guandu e crotalária promoveu $100 \%$ de controle da murcha, em todas as concentrações avaliadas. Com 60 dias de incubação, apenas a concentração de 10 $\%$ de guandu e crotalária não controlou a doença. Esses resultados indicam que a incorporação no solo com a parte aérea de guandu e crotalária é um método eficiente para o controle da murcha bacteriana do tomateiro.

Palavras-chave adicionais: Lycopersicon esculentum, Ralstonia solanacearum, Cajanus cajan, Crotalaria juncea, compostos orgânicos. 
Tomato (Lycopersicon esculentum Mill.) is susceptible to several pathogens. Bacterial wilt caused by Ralstonia solanacearum (Smith) Yabuuchi et al., is the most important bacterial disease of tomato crops (11). This disease occurs in all regions of Brazil (16) and causes irreversible damage to tomato plants, under favorable environmental conditions for disease establishment (high humidity and temperature) (11).

Bacterial wilt caused by $R$. solanacearum biovar III has been diagnosed in areas of small farmers that produce solanaceae species such as tomato, eggplant, and green peppers, in the Recôncavo region of Bahia, Brazil (unpublished data). These farmers have searched for control strategies and some have abandoned their plantations due to the losses caused by this and other diseases. The control of bacterial wilt is difficult. Crop rotation, although recommended, is not an efficient method, since $R$. solanacearum has its disseminating and survival stages in the soil (12), and it remains viable for long periods of time, hindering the growth of susceptible crops for several years in the same place (17).

The incorporation of organic matter to soil has been a viable alternative for plant disease control, especially for soilborne phytopathogenic fungi (22). However, Uesugi \& Tomita (21) reported that increasing levels of organic matter in soil increased the incidence of bacterial wilt. Therefore, there are no reports about the efficient control of tomato bacterial wilt through the use of organic matter.

Organic matter improves the physical, chemical and biological soil properties. It has been studied as an inducer of suppressiveness to soilborne phytopathogenic fungi (8). These characteristics and the environmental factors increase or inhibit disease development, due to their effect on the inoculum's survival (15). The induction of soil suppressiveness can occur with the increase of antagonistic microorganisms, adequate cultural practices or other management strategies (4). Organic matter decomposition can result in compounds that stimulate or inhibit pathogen propagules. Therefore, a careful evaluation is necessary before using organic matter for control of soilborne plant pathogens (22).

Uesugi \& Tomita (21) observed that the incidence of bacterial wilt increased in the treatments with the higher levels of organic matter and in those with sterilized organic matter, when compared to treatments with unsterilized organic compost. The studies with organic matter have shown that the efficiency of disease control depends on several factors such as: the crop, the pathogen, the type of organic matter incorporated to soil, the carbonnitrogen ratio, and the degree of organic matter decomposition $(7,8)$. Organic residues increase soil microbial activity and competition, which can cause the lysis of pathogen cell components and the promotion of plant growth $(2,6)$. However, certain organic residues can increase the disease incidence, due to the supply of nutrients for the pathogens, which increases their survival in soil (5).

This work aimed to study the effects of soil incorporation of different sources and levels of organic matter on the tomato bacterial wilt control.

\section{MATERIAL AND METHODS}

This work was conducted under greenhouse conditions, in the city of Cruz das Almas, State of Bahia, Brazil, from April to August of 2003 , with average temperature of $23.8^{\circ} \mathrm{C}$, relative air humidity $88.8 \%$ and luminosity of $70 \%$.

Stage 1. Experiment with green manure incubated for 30 days and local available organic composts

The following organic composts were tested: 1 - Ecofertil ${ }^{\circledR}$ (EC), composed by sugar cane residues, animal manure (chicken and cattle) and rock powder (MP4) already composted; 2 - Cofertil ${ }^{\circledR}(\mathrm{CF})$, composed of a mixture of animal manure (cattle and goat) already composted; 3 - freshly cut aerial parts of pigeon pea (Cajanus cajan) and 4 - freshly cut aerial parts of crotalaria (Crotalaria juncea). All sources of organic matter were incorporated to soil in the concentrations of 10, 20 and $30 \%$ (v/v) (Table 1), which were defined based on Soares et al. (20) and Schoenmaker \& Ghini (19).

The fresh matter of pigeon pea and crotalaria were cut in an animal forage cutter, incorporated to the soil infested with $R$. solanacearum and maintained in plastic bags $(15 \mathrm{~L}$ of the mixture per bag) for a 30-day incubation. The humidity of the mixture was maintained near field capacity. The commercially available composts (Ecofertil and Cofertil) were incorporated to the soil, also in the concentrations of 10,20 and $30 \%(\mathrm{v} / \mathrm{v})$, at the time of seedling transplanting. The soil amended with Ecofertil and Cofertil (composted organic matter) was not incubated for 30 days.

The infested soil was obtained from a layer of 0 to $20 \mathrm{~cm}$ of an area with $R$. solanacearum biovar III. This area had been previously infested with the pathogen by planting tomato seedlings inoculated with $R$. solanacearum, followed by soil incorporation of tomato plants with wilting symptoms, for three consecutive planting periods. The homogeneity of the infested area was tested with the planting of healthy tomato cv. Santa Clara seedlings and observation of $100 \%$ bacterial wilt incidence.

The two utilized control treatments were: control 1 - soil obtained from the infested area and maintained humid throughout the 30 day incubation period (incubated soil) for comparisons with the treatments with pigeon pea and crotalaria; control 2 -

Table 1 - Description of the treatments for stage 1

\begin{tabular}{cc}
\hline Treatments & Planting substrates \\
\hline Control 1 & Infested soil, wet and incubated \\
Control 2 & Infested soil without incubation \\
T1 & Infested soil $+10 \%$ pigeon pea \\
T2 & Infested soil $+20 \%$ pigeon pea \\
T3 & Infested soil $+30 \%$ pigeon pea \\
T4 & Infested soil $+10 \%$ crotalaria \\
T5 & Infested soil $+20 \%$ crotalaria \\
T6 & Infested soil $+30 \%$ crotalaria \\
T7 & Infested soil $+10 \%$ Ecofertil ${ }^{\circledR}$ \\
T8 & Infested soil $+20 \%$ Ecofertil ${ }^{\circledR}$ \\
T9 & Infested soil $+30 \%$ Ecofertil ${ }^{\circledR}$ \\
T10 & Infested soil $+10 \%$ Cofertil ${ }^{\circledR}$ \\
T11 & Infested soil $+20 \%$ Cofertil ${ }^{\circledR}$ \\
T12 & Infested soil $+30 \%$ Cofertil ${ }^{\circledR}$ \\
&
\end{tabular}


soil obtained from the infested area at the same day the tomato seedlings were transplanted (soil without incubation) for the commercially available organic composts (Table 1). The soil microbial activity is altered when soil humidity is maintained near field capacity (unpublished data). This fact explains the choice of the two control treatments.

For seedling production, tomato seeds cv. Santa Clara were sown in plastic trays with 40 holes. Twenty days after sowing, the seedlings were transplanted to polyethylene plastic bags with $3 \mathrm{~kg}$ of the planting substrate (infested soil + organic matter). The bacterial wilt symptoms were evaluated for a period of 45 days and the bacterial exudation test was performed on the plants with wilting. For measurements and disease comparisons, a disease index was calculated (DI) based on the period of incubation. Therefore, DI = period of disease symptoms divided by the number of days evaluated (45 days). The percentage of flowering plants and the dry weight of the plant aerial parts were evaluated at the end of the experiment.

The experiment was carried on in a completely randomized design, in the factorial scheme $4 \times 3+2$, comprising four sources of organic matter, three concentrations and two controls, with five replicates for each treatment. The experimental plot was composed of two plants in a plastic bag with $3 \mathrm{~kg}$ of substrate. days

Stage 2. Experiment with green manure incubated for 60

The organic matter tested was: freshly cut aerial parts of pigeon pea (Cajanus cajan) and crotalaria (Crotalaria juncea) in concentrations of 10, 20, and $30 \%(\mathrm{v} / \mathrm{v})$.

The fresh matter of pigeon pea and crotalaria were incorporated into soil infested with $R$. solanacearum and incubated in plastic bags (15L of substrate/bag) for 60 days with the humidity maintained near field capacity. The control treatment was soil obtained from the area infested with $R$. solanacearum and incubated in a plastic bag with the humidity near field capacity, for a period of 60 days. Twenty days after sowing, tomato seedlings were transplanted to polyethylene bags with $3 \mathrm{~kg}$ of planting substrate.

The experiment was carried out in a completely randomized design, in the factorial scheme $2 \times 3+1$, comprising two types of green manure (pigeon pea and crotalaria), three concentrations and the control treatment without organic matter, with five replicates per treatment. The experimental plot was composed of two plants in a plastic bag with $3 \mathrm{~kg}$ of planting substrate. trates

Quantification of the microbial community in the subs-

At the end of the experiment (45 days after seedling transplanting), samples of the plant growth substrates were collected for each treatment, for microbial community quantification. Four serial dilutions (1:10) with $0.85 \% \mathrm{NaCl}$ were done for each sample, followed by plating $(100 \mu \mathrm{L}$ of each dilution $\mathrm{x} 3$ replicates $)$ and spreading in the culture media. The plated dilutions $10^{-2}$ and $10^{-3}$ were for fungi counting and $10^{-3}$ and $10^{-4}$ for bacterial counting. The Martin culture media with streptomycin $\left(100 \mu \mathrm{L}^{-\mathrm{L}^{-1}}\right)$ and nutrient agar culture media with cyclohexamide $\left(100 \mu \mathrm{L} . \mathrm{L}^{-1}\right)$ were used for quantification of fungi and bacteria, respectively (10). The cultures were incubated at temperature of $28^{\circ} \mathrm{C}$ and the colonies of bacteria and fungi were counted after 24 and 48 hours, respectively.

Quantification of microbial activity (basal respiration)

Soil microbial respiration $\left(\mathrm{CO}_{2}\right.$ production) was determined in agreement with the methodology described by Isermeyer (1952) cited by Alef and Nannipieri (1).

\section{Statistical analysis:}

The disease index data was transformed in arcsen vx, and all data were submitted to ANOVA analyses. The regression analysis was done for the variables that presented significant differences for organic matter concentration. The average comparisons were done by the test of Tukey and the T-test at the level of $5 \%$ probability. The statistical software SAS - Statistical Analysis System was used (18).

\section{RESULTS AND DISCUSSION}

\section{Stage 1. Green manure incubated for 30 days and orga- nic composts}

The aerial parts of pigeon pea and crotalaria incorporated into the soil infested with $R$. solanacearum allowed $100 \%$ disease control in all concentrations tested (Table 2 and Figure 1). The disease index did not differ for the treatments with pigeon pea and crotalaria, regardless of the tested concentration, as well as for the treatment with Cofertil $^{\circledR}(\mathrm{CF})$ in the concentration of 30 $\%$ (Table 2).

Increasing the concentration of the $\mathrm{CF}$ compost promoted a better control of the disease (Table 2). CF in the concentration of $30 \%$ allowed a disease index of 1.0 or $100 \%$ disease control. However, the plants did not grow well and showed $0 \%$ of flowering (Table 3). This fact also occurred with the EC compost (Table 4).

Green manure provided $100 \%$ control of bacterial wilt and the development of the tomato plants was also significantly superior for all concentrations tested (Tables 2 and 4). This is probably a result of the improved chemical and biological characteristics of the plant growth substrate due to soil incorporation of the green manure. Incorporation of organic matter into soil causes improvement of its physical characteristics and adds a source of exogenous energy, which stimulates the microbial activity (22).

Table 2. Disease index of tomato plants cv. Santa Clara in response to different sources and concentrations of organic matter.

\begin{tabular}{ccccc}
\hline \multirow{2}{*}{ Treatments } & \multicolumn{3}{c}{ Concentrations } & \multirow{2}{*}{ Average } \\
\cline { 2 - 4 } & $\mathbf{1 0} \%$ & $\mathbf{2 0} \%$ & $\mathbf{3 0} \%$ & \\
\hline Pigeon pea & $1.0 \mathrm{Aa}$ & $1.0 \mathrm{Aa}$ & $1.0 \mathrm{Aa}$ & 1.0 \\
Crotalaria & $1.0 \mathrm{Aa}$ & $1.0 \mathrm{Aa}$ & $1.0 \mathrm{Aa}$ & 1.0 \\
Ecofertil & $0.332 \mathrm{Ba}$ & $0.549 \mathrm{Ba}$ & $0.469 \mathrm{Ba}$ & 0.450 \\
Cofertil & $0.306 \mathrm{Bc}$ & $0.744 \mathrm{Bb}$ & $1.0 \mathrm{Aa}$ & 0.683 \\
\hline Average & 0.659 & 0.823 & 0.867 & \\
\hline Control 1 & \multicolumn{5}{c}{0.576} \\
\hline Control 2 & & & 0.720 \\
\hline
\end{tabular}

Means within columns followed by the same capital letter and within lines followed by the same small letter are not significantly different, according to the test of Tukey at $5 \%$ of probability. $\mathrm{VC}=17.43 \%$. Control 1 = incubated soil; control 2 = soil without incubation. 


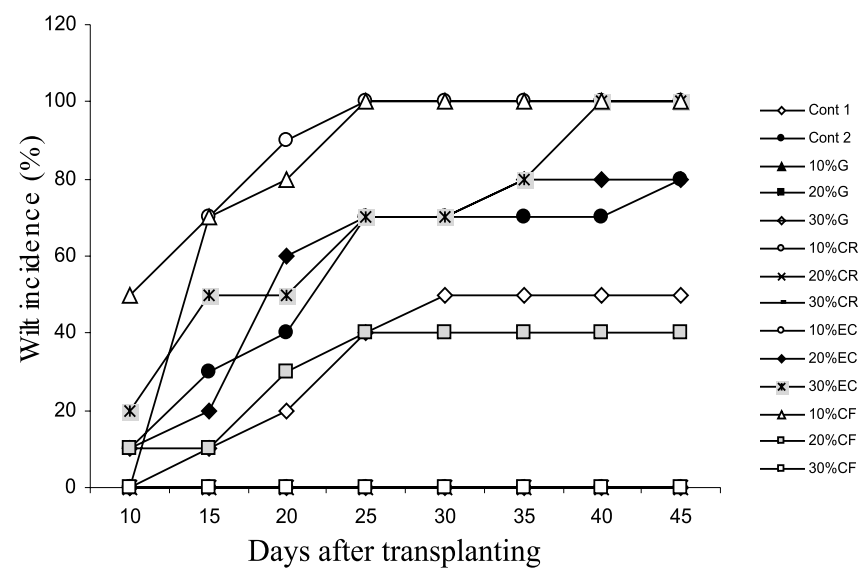

Figure 1. Average percentage of tomato plants cv Santa Clara with bacterial wilt symptoms, in different treatments. Soil amended with pigeon pea - Cajanus cajan (G) and crotalaria - Crotalaria juncea (CR) and incubated for 30 days. Soil amended with the organic composts Ecofertil® (EC) and Cofertil ${ }^{\circledR}(\mathrm{CF})$, without incubation. Cont 1 (incubated soil) and Cont 2 (soil without incubation). The disease-progress curves for the treatments with G, CR, and EC $30 \%$ are in the $\mathrm{X}$-axis.

Table 3. Percentage of flowering tomato plants, cv. Santa Clara, in response to the different sources and concentrations of organic matter.

\begin{tabular}{ccccc}
\hline Treatments & \multicolumn{4}{c}{ Concentrations } \\
\cline { 2 - 5 } & $\mathbf{0} \%$ & $\mathbf{1 0} \%$ & $\mathbf{2 0} \%$ & $\mathbf{3 0} \%$ \\
\hline Pigeon pea & - & 90 & 80 & 90 \\
Crotalaria & - & 90 & 100 & 100 \\
Ecofertil & - & 90 & 0 & 0 \\
Cofertil & - & 0 & 0 & 0 \\
\hline Control 1 & 0 & & & \\
\hline Control 2 & 30 & & \\
\hline
\end{tabular}

The enrichment of the soil chemical characteristics and growth promotion of tomato plants with the soil incorporation of fresh matter of pigeon pea was observed by Soares et al. (20).

The soil incorporated with pigeon pea and crotalaria presented higher values of bacterial colony forming units (cfu), when compared with the treatments with EC, $\mathrm{CF}$ and the controls (Table 5). Higher values of fungi colony forming units were also observed for the treatments with pigeon pea and crotalaria in the concentrations of 20 and $30 \%$. Green manure stimulated the growth of the soil microbial population.

The soil incorporated with pigeon pea presented higher quantities of $\mathrm{CO}_{2}$ production, for the concentrations of 20 and $30 \%$, demonstrating a higher microbial activity, when compared to the treatments with crotalaria. The treatments with pigeon pea and crotalaria had higher values of $\mathrm{CO}_{2}$ production than the control treatments (Table 6). These results give support to the hypothesis
Table 4. Dry weight matter (g) of tomato plants cv. Santa Clara in response to different sources and concentrations of organic matter.

\begin{tabular}{ccccc}
\hline \multirow{2}{*}{ Treatments } & \multicolumn{3}{c}{ Concentrations } & \multirow{2}{*}{ Average } \\
\cline { 2 - 4 } & $\mathbf{1 0} \%$ & $\mathbf{2 0} \%$ & $\mathbf{3 0} \%$ & \\
\hline Pigeon pea & $15.75 \mathrm{Aa}$ & $12.17 \mathrm{Ab}$ & $15.60 \mathrm{Aa}$ & 14.30 \\
Crotalaria & $15.49 \mathrm{Ab}$ & $14.05 \mathrm{Ab}$ & $19.62 \mathrm{Aa}$ & 16.65 \\
Ecofertil & - & $0.67 \mathrm{~B}$ & - & 0.67 \\
Cofertil & - & $1.71 \mathrm{Ba}$ & $1.26 \mathrm{Ba}$ & 1.39 \\
\hline Average & 15.32 & 9.99 & 12.15 & \\
\hline Control 1 & \multicolumn{5}{c}{7.90} \\
\hline Control 2 & \multicolumn{5}{c}{1.02} \\
\hline
\end{tabular}

Means within columns followed by the same capital letter and within lines followed by the same small letter are not significantly different, according to the test of Tukey at $5 \%$ of probability. CV $=20.63 \%$. Control 1= incubated soil; Control 2= soil without incubation.

that the soil microbial activity increases with the incorporation of green manure. This condition explains the control of tomato bacterial wilting in the present work. According to Cook \& Baker (2) and Huang \& Kuhlman (6), organic residues can increase soil microbial activity and the competition between the microorganisms, promoting cell lyses of the plant pathogens and plant growth.

Uesugi \& Tomita (21) studied the effect of compost in the control of bacterial wilt. The compost had residues of sugar cane and a leguminous plant, and coarse castor bean meal (Ricinus communis L.) plus Bokashi. This mixture was incorporated to autoclaved soil. An increase in the percentage of plants with wilt symptoms was observed, varying from $40 \%$ to $94 \%$. High levels of organic matter caused an increase of bacterial wilt symptoms. The unsterilized compost was not efficient for bacterial wilt control, but presented better results when compared to the sterilized compost. This fact demonstrates the importance of the organic matter biotic factor for disease control.

The efficient control of bacterial wilt with the incorporation of pigeon pea and crotalaria to soil could be due to the fact that the decomposition of organic matter occurred in the infested soil, while the incorporation of already decomposed organic matter (Ecofertil and Cofertil) did not stimulate soil microbial activity. Soil incorporation of different plant species as green manure for the control of soilborne phytopathogenic fungi has been studied by Costa (3). The crotalaria has been studied for the control of plant parasitic nematodes (23). However, this is the first report of the efficient control of tomato bacterial wilt with soil incorporation of pigeon pea and crotalaria.

Step 2. Green manure incubated for 60 days.

The treatments with $10 \%$ of pigeon pea and crotalaria did not control the disease and the treatment with $10 \%$ crotalaria increased the disease incidence (Figure 2, Table 7). The levels of 20 and $30 \%$ of green manure gave $100 \%$ disease control. The effect of organic matter on the pathogen varies with the type of organic matter incorporated to soil, the carbon-nitrogen ratio, the 
Table 5. Total number (cfu - colony forming units) of bacteria and fungi in soil with incorporation of fresh aerial parts of pigeon pea (Cajanus cajan), crotalaria (Crotalaria juncea), Ecofertil® and Cofertil®.

\begin{tabular}{|c|c|c|c|c|}
\hline \multirow[t]{2}{*}{ Treatments } & \multicolumn{3}{|c|}{ Concentrations } & \multirow[t]{2}{*}{ Average } \\
\hline & $10 \%$ & $20 \%$ & $30 \%$ & \\
\hline Pigeon pea & $24.1 \mathrm{Ab}$ & $36.9 \mathrm{Aa}$ & $33.6 \mathrm{Ba}$ & 31.52 \\
\hline Cofertil & $2.30 \mathrm{Cb}$ & $6.15 \mathrm{Ba}$ & $2.68 \mathrm{Dab}$ & 3.68 \\
\hline Average & 11.24 & 21.28 & 26.75 & \\
\hline Control 1 & & & & 2.17 \\
\hline Crotalaria & $6.29 \mathrm{Bb}$ & 13.77 Aba & $16.86 \mathrm{Aa}$ & 12.31 \\
\hline Ecofertil & $3.31 \mathrm{Ba}$ & $3.19 \mathrm{Ca}$ & $2.20 \mathrm{Ba}$ & 2.90 \\
\hline Cofertil & $3.46 \mathrm{Bb}$ & $9.20 \mathrm{Bca}$ & $5.04 \mathrm{Bab}$ & 5.90 \\
\hline Average & 6.58 & 10.84 & 11.34 & \\
\hline Control 1 & & & & 6.21 \\
\hline Control 2 & & & & 3.38 \\
\hline
\end{tabular}

Means within columns followed by the same capital letter and within lines followed by the same small letter are not significantly different according to the test of Tukey at $5 \%$ of probability. VC Bacteria $=10.66 \%$ VC Fungi $=30.82 \%$. Control $1=$ incubated soil; control $2=$ soil without incubation.

Table 6. Soil microbial respiration after incorporation of different concentrations of aerial parts of pigeon pea (Cajanus cajan) and crotalaria (Crotalaria juncea) and incubation for 30 days.

\begin{tabular}{ccccc}
\hline & \multicolumn{3}{c}{$\begin{array}{c}\text { Microbial respiration } \\
\left(\mathbf{C O}^{\mathbf{2}}(\mathbf{u g}) / \mathbf{g D S} / \mathbf{h}\right)^{\mathbf{1}}\end{array}$} & \\
\cline { 2 - 4 } Treatments & \multicolumn{3}{c}{ Concentrations } & \\
\cline { 2 - 4 } & $\mathbf{1 0} \%$ & $\mathbf{2 0} \%$ & $\mathbf{3 0} \%$ & \\
\hline Pigeon pea & $8.52 \mathrm{Ab}$ & $13.81 \mathrm{Aa}$ & $13.97 \mathrm{Aa}$ & 12.10 \\
Crotalaria & $7.11 \mathrm{Aa}$ & $6.44 \mathrm{Ba}$ & $6.12 \mathrm{Ba}$ & 6.56 \\
\hline Average & 7.81 & 10.13 & 10.04 & \\
\hline Control & \multicolumn{4}{c}{4.72} \\
\hline
\end{tabular}

Means within columns followed by the same capital letter are not significantly different, according to the T-test and means within lines followed by the same small letter are not significantly different, according to the test of Tukey, at $5 \%$ of probability. $\mathrm{VC}=13.37 \%$. ${ }^{1} \mathrm{CO}_{2}$ production in $\mu \mathrm{g}$ per gram of dry soil per hour.

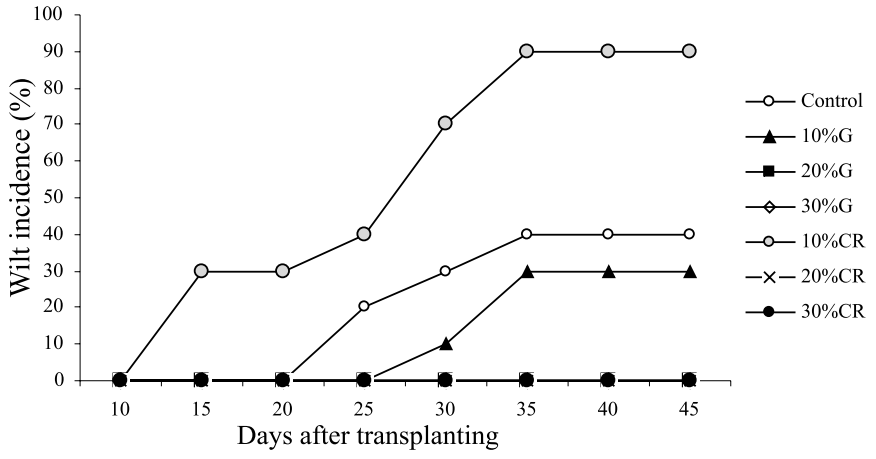

Figure 2. Average percentage of tomato plants cv Santa Clara with bacterial wilt symptoms, in different treatments. Soil amended with pigeon pea - Cajanus cajan (G) and crotalaria - Crotalaria juncea (CR) and incubated for 60 days. Control - soil without Gand CR. The disease-progress curves for the treatments with $\mathrm{G}$ and $\mathrm{CR}$, in the concentrations of 20 and $30 \%$ are in the $\mathrm{X}$-axis. 
degree of decomposition, and other factors (7).

The population of bacteria and fungi was greater in the treatment with pigeon pea, when compared to the crotalaria treatments (Table 8). For the soil microbial respiration, significant differences were observed only for the treatment with $30 \%$ of pigeon pea (Table 9). According to Moreira and Siqueira (14), $\mathrm{CO}_{2}$ production is an indicator of the degree of decomposition of the organic matter. The fraction formed by substrates readily

Table 7. Disease index of tomato plants cv. Santa Clara in response to different sources and concentrations of organic matter.

\begin{tabular}{ccccc}
\hline \multirow{2}{*}{ Treatments } & \multicolumn{3}{c}{ Concentrations } & Average \\
\cline { 2 - 4 } & $\mathbf{1 0} \%$ & $\mathbf{2 0} \%$ & $\mathbf{3 0} \%$ & \\
\hline Pigeon pea & $0.900 \mathrm{Aa}$ & $1.0 \mathrm{Aa}$ & $1.0 \mathrm{Aa}$ & 0.966 \\
Crotalaria & $0.538 \mathrm{Bb}$ & $1.0 \mathrm{Aa}$ & $1.0 \mathrm{Aa}$ & 0.846 \\
\hline Average & 0.719 & 1.0 & 1.0 & \\
\hline Control & & & & 0.847 \\
\hline
\end{tabular}

Means within columns followed by the same capital letter are not significantly different, according to the T-test and means within lines followed by the same small letter are not significantly different, according to the test of Tukey, at $5 \%$ of probability.

Table 8. Total number (CFU - colony forming units) of soil bacteria and fungi, after the incorporation of different concentrations of fresh aerial part of pigeon pea (Cajanus cajan) and crotalaria (Crotalaria juncea) into soil, followed by incubation for 60 days before planting.

\begin{tabular}{|c|c|c|c|c|}
\hline \multirow{3}{*}{ Treatments } & \multirow{2}{*}{\multicolumn{3}{|c|}{$\begin{array}{c}\begin{array}{c}\text { Quantification of bacteria } \\
\left.\text { (CFU } \times 10^{5} / \mathrm{g} \text { soil }\right)\end{array} \\
\text { Concentrations }\end{array}$}} & \multirow{3}{*}{ Average } \\
\hline & & & & \\
\hline & $10 \%$ & $20 \%$ & $30 \%$ & \\
\hline Pigeon pea & $17.08 \mathrm{Ac}$ & $55.51 \mathrm{Aa}$ & $33.53 \mathrm{Ab}$ & 35.37 \\
\hline Crotalaria & $25.17 \mathrm{Aab}$ & $37.76 \mathrm{Ba}$ & $14.25 \mathrm{Bb}$ & 25.73 \\
\hline Average & 21.12 & 46.64 & 23.89 & \\
\hline Control & & & & 2.17 \\
\hline Treatments & $\begin{array}{r}\text { Quant } \\
\text { (CF }\end{array}$ & $\begin{array}{l}\text { fication of } \\
U \times 10^{5} / g \text { s }\end{array}$ & $\begin{array}{l}\text { fungi } \\
\text { oil) }\end{array}$ & \\
\hline Pigeon pea & $10.97 \mathrm{Ac}$ & $47.50 \mathrm{Ba}$ & $97.89 \mathrm{Ab}$ & 50.12 \\
\hline Crotalaria & $5.65 \mathrm{Ab}$ & $115.29 \mathrm{Aa}$ & $5.32 \mathrm{Bb}$ & 42.09 \\
\hline Average & 8.31 & 81.40 & 48.61 & \\
\hline Control & & & & 6.01 \\
\hline
\end{tabular}

Means within columns followed by the same capital letter are not significantly different, according to the T-test and means within lines followed by the same small letter are not significantly different, according to the test of Tukey, at $5 \%$ of probability. VC Bacteria $=$ $22.32 \% ; \mathrm{VC}$ Fungi $=12.46 \%$. available is rapidly converted into $\mathrm{CO}_{2}$ and microbial biomass. The production of $\mathrm{CO}_{2}$ did not differ for most of the treatments with green manure, possibly due to the stabilization of the organic matter. Therefore, the production of $\mathrm{CO}_{2}$ and the soil microbial population are not sufficient parameters to explain the efficient disease control. There are other factors involved. The effects induced by organic matter on soilborne phytopathogenic fungi, through the microbial community, can occur by competition, antibiosis, pathogen cell lysis and the production of toxic metabolites (9).

Pigeon pea and crotalaria promoted significant increases of plant biomass dry weight, when compared to the treatment without the incorporation of green manure. The treatments with green manure did not differ among them (Table 10). This may have occurred due to the limiting space for root growth in the recipient. These treatments also allowed a high percentage of flowering, with exception of treatment with $10 \%$ crotalaria, that also had the highest percentage of plants with wilt symptoms (Tables 7 and 11).

The incorporation of 20 to $100 \%$ of organic matter is possible for plant growth substrates during the sowing process for seedling production, while the level of organic matter incorporated into the soil should be around $2 \%$, in order to be considered economically viable (21). For the present work, $10 \%$ (v/v) of fresh aerial part of pigeon pea or crotalaria, incubated for 60 days before transplanting the tomato seedlings, was not efficient for the control of bacterial wilt. However, since green manure can be produced in the farm at a low cost, its incorporation at much higher levels into the soil is economically viable.

Incorporation of 20 to $30 \%$ of the aerial part of pigeon pea (Cajanus cajan) and crotalaria (Crotalaria juncea) into the soil promoted $100 \%$ control of tomato bacterial wilt (Tables $2 \& 7$ ). This is an efficient disease control strategy. Future work can evaluate these sources of green manure for bacterial wilt control under field conditions and determine the adequate level for efficient control. Green manure is an inexpensive source of organic matter and it improves the chemical, physical and microbial soil

Table 9. Soil microbial respiration after incorporation of different concentrations of aerial parts of pigeon pea (Cajanus cajan) and crotalaria (Crotalaria juncea) and incubation for 60 days before planting.

\begin{tabular}{ccccc}
\hline & \multicolumn{3}{c}{$\begin{array}{c}\text { Microbial respiration } \\
\left(\mathbf{C O}_{\mathbf{2}}(\mathbf{u g}) / \mathbf{g D S} / \mathbf{h}\right)\end{array}$} & \\
\cline { 2 - 4 } Treatments & \multicolumn{3}{c}{ Concentrations } & \\
\cline { 2 - 4 } & $\mathbf{1 0} \%$ & $\mathbf{2 0} \%$ & $\mathbf{3 0} \%$ & \\
\hline Pigeon pea & $6.26 \mathrm{Ab}$ & $7.20 \mathrm{Ab}$ & $14.66 \mathrm{Aa}$ & 9.37 \\
Crotalaria & $7.35 \mathrm{Aa}$ & $9.04 \mathrm{Aa}$ & $8.34 \mathrm{Ba}$ & 8.24 \\
\hline Average & 6.81 & 8.12 & 14.66 \\
\hline Control & \multicolumn{4}{c}{5.06} \\
\hline
\end{tabular}

Means within columns followed by the same capital letter are not significantly different, according to the T-test and means within lines followed by the same small letter are not significantly different, according to the test of Tukey, at $5 \%$ of probability. $\mathrm{VC}=22.72 \%$. ${ }^{1} \mathrm{CO}_{2}$ production in $\mu \mathrm{g}$ per gram of dry soil per hour. 
Table 10. Dry weight matter (g) of tomato plants cv. Santa Clara in response to different sources and levels of organic matter.

\begin{tabular}{lcccc}
\hline \multirow{2}{*}{ Treatments } & \multicolumn{3}{c}{ Concentrations } & Average \\
\cline { 2 - 4 } & $\mathbf{1 0 \%}$ & $\mathbf{2 0} \%$ & $\mathbf{3 0} \%$ & \\
\hline Pigeon pea & $15.95 \mathrm{Aa}$ & $12.95 \mathrm{Aa}$ & $13.99 \mathrm{Aa}$ & 14.27 \\
Crotalaria & $9.82 \mathrm{Aa}$ & $9.11 \mathrm{Aa}$ & $16.20 \mathrm{Aa}$ & 12.40 \\
\hline Average & 14.72 & 10.82 & 15.09 & \\
\hline Control & & & & 3.40 \\
\hline
\end{tabular}

Means within columns followed by the same capital letter are not significantly different, according to the T-test and means within lines followed by the same small letter are not significantly different, according to the test of Tukey, at $5 \%$ of probability. $\mathrm{VC}=44.12 \%$.

Table 11. Percentage of flowering tomato plants cv. Santa Clara in response to different sources and levels of organic matter.

\begin{tabular}{ccccc}
\hline Treatments & \multicolumn{4}{c}{ Concentrations } \\
\cline { 2 - 5 } & $\mathbf{0} \%$ & $\mathbf{1 0} \%$ & $\mathbf{2 0} \%$ & $\mathbf{3 0} \%$ \\
\hline Pigeon pea & - & 70 & 70 & 100 \\
Crotalaria & - & 0 & 60 & 100 \\
\hline Control & 0 & & & \\
\hline
\end{tabular}

characteristics and promotes plant growth. The crotalaria is also indicated for the control of plant parasitic nematodes such as Meloidogyne sp. that affect tomato plants, while pigeon pea is a susceptible host for these plant nematodes (13).

\section{REFERENCES}

1. Alef, K.; Nannipieri, P. Methods in applied microbiology and biochemistry. London: Academic Press, 1995. 576p.

2. Cook, R.J.; Baker, K.F. The nature and practice of biological control of plant pathogens. St. Paul: The American Phytopathological Society, 1983. 53p.

3. Costa, J.L. da S. Reconstrução do solo e manejo de culturas no controle de podridões radiculares em feijoeiro. Fitopatologia Brasileira, Brasília, v.26, supl., p.37-38. 2002.

4. Ghini, R.; Zaroni, M.M.H. Relação entre coberturas vegetais e supressividade de solos a Rhizoctonia solani. Fitopatologia Brasileira, Brasília, v.26, n.1, p.10-15, 2001.

5. Grünwald, N.J.; Hu, S.; Bruggen, A.H.C. Short-term cover crop decomposition in organic and conventional soils: characterization of soil C, N, microbial and plant pathogen dynamics. European Journal of Plant Pathology, Dordrecht, v.106, n.1, p.37-50, 2000.

6. Huang, J.W.; Kuhlman, E.G. Mechanisms inhibiting damping-off pathogens of slash pine seedlings with a formulation soil amendment. Phytopathology, St. Paul, v.81,-n.3, p.171-177, 1991.

7. Hoitink, H.A.J; Fahy, P.C. Basis for control of soil borne plant pathogens with composts. Annual Review of Phytopathology, Palo Alto, v.24, p.93-114, 1986.
8. Hoitink, H.A.J.; Boehm, M.J. Biocontrol within the context of soil microbial communities: a substrate-dependent phenomenon. Annual Review of Phytopathology, Palo Alto, v.7, p.427-446, 1999.

9. Hornby, D. Biological control of soilborne plant pathogens. Wallingford: CAB International, 1990. 479p.

10. Klement, Z.; Rudolph, K.; Sands, D.C. Methods in phytobacteriology. Budapest: Akadémiai Kiado, 1990. 468p.

11. Lopes, C.A.; Santos, J.R.M. dos. Doenças do tomateiro. Brasília: Embrapa-SPI/ Embrapa-CNPH, 1994. 61p.

12. Michereff, S.J. et al. Manejo sustentável de doenças radiculares em solos tropicais. In: Michereff, S. J.; Barros, R. (Ed.). Proteção de plantas na agricultura sustentável. Recife: UFRPE, 2001, p.15-70.

13. Mondardo, E.; Moraes, O. de; Morel, D.A.; Miura, L.; Schmitt, A. T. Leguminosas para adubação verde em solos arenosos do sul de Santa Catarina. Florianópolis: EMPASC, 1981. 13p. (Comunicado Técnico, 43).

14. Moreira, F.M.S.; Siqueira, J.O. Matéria orgânica do solo. In: Moreira, F.M.S.; Siqueira, J.O. (Ed.). Microbiologia e bioquímica do solo. Lavras: Editora UFLA,. 2002. p.191-241.

15. Nelson, P.E. Life cycle and epidemiology of Fusarium oxysporum. In: Mace, M.E.; Bell, A.A.; Beckman, C.H. (Ed.). Fungal wilt diseases of plants. New York:Academic Press, 1981. p.5180.

16. Reifschneider, F.J.B.; Takatsu, A. Pseudomonas solanacearum no Brasil: aspectos macroepidemiológicos. Fitopatologia Brasileira, Brasília, v.10, n.2, p.213, 1985.

17. Romeiro, R. S. Bactérias fitopatogênicas. Viçosa: UFV, 1995. 281p.

18. SAS Institute. SAS/STAT: user's guide v.8.0. Cary, 2000. v.1.

19. Schoenmaker, I.A.S.; Ghini, R. Biofumigação do solo para o controle de Pythium spp. Summa Phytopathologica, Jaboticabal, v.27, n.3, p.308-309, 2001.

20. Soares, A.C.F.; Santiago, D.; Souza, I.C.C.; Garrido M.S. Produção de mudas de tomateiro em substratos com diferentes proporções de matéria fresca de guandu (Cajanus cajan). In: FERTBIO 2002, Reunião Brasileira de Fertilidade do Solo e Nutrição de Plantas, 25., 2002, Rio de Janeiro. Anais... Universidade Federal Rural do Rio de Janeiro. 2002. 1 CD-ROM.

21. Uesugi, C.H.; Tomita, C.K. Murcha bacteriana. Revista Cultivar HF, Pelotas, ano 2, n.11, p.12-14, dez. 2001/ jan.2002.

22. Viana, F.M.P. et al. Controle do tombamento de plântulas de feijoeiro causado por Sclerotinia sclerotiorum com a incorporação de matéria orgânica ao substrato. Summa Phytopathologica, Jaboticabal, v.26, n.1, p.95-97, 2000.

23. Wang, K-H.; Sipes, B. S.; Schmitt, D.P. Crotalaria as a cover crop for nematode management: a review. Nematropica, Gainesville, v.32, n.1, p.35-57, 2002. 